\title{
Factors affecting the summer carbon dioxide budget of subarctic wetland tundra
}

\author{
Kimberley L. Burton*, Wayne R. Rouse, L. Dale Boudreau \\ Department of Geography, McMaster University, Hamilton, Ontario, Canada L8S 4K1
}

\begin{abstract}
This study reports on 27 days of $\mathrm{CO}_{2}$ flux measurements from wetland tundra in the vicinity of Churchill, Manitoba, Canada. Fluxes were measured continuously using a portable, gradient measurement system which is described in detail. The measurements apply to a climatically normal summer in terms of solar radiation, temperature and precipitation. The environment consists of a hummocky fen underlain by permafrost with a thick layer of organic soils. Sedges dominated the hummocks and mosses the hollows. The measurement period was composed of a dry period when the water table receded below the lowest terrain elements and a wet period when there was standing water in the hollows. On average for the measurement period, and on most days, the carbon balance was positive, meaning that carbon loss through respiration exceeded the gain through photosynthesis. Respiration was greater and photosynthesis less during the dry period than the wet period. The magnitude of the daily average $\mathrm{CO}_{2}$ flux in this study was comparable to summer fluxes measured in similar ecosystems. The implications of a net carbon loss during the most photosynthetically active period are discussed.
\end{abstract}

KEY WORDS: $\mathrm{CO}_{2}$ flux $\cdot$ Carbon dioxide budget $\cdot$ Wetland $\cdot$ Fen $\cdot$ Subarctic

\section{INTRODUCTION}

It is estimated that $28 \%$ of global soil carbon is sequestered in peat (Gorham 1991). In Canada over $85 \%$ of wetlands are peatlands (NWWG 1988). They play an important role in the global carbon cycle. The largest contiguous area of wetlands and peatlands in North America and the second largest in the world is the Hudson Bay Lowland (Mortsch 1990). This study applies to wetlands in the northern portion of the Hudson Bay Lowland which is underlain by continuous permafrost.

Several studies suggest that soil carbon can be both a significant source (Woodwell 1983, Houghton 1991. Townsend et al. 1992) and sink (Tans et al. 1990, Harrison et al. 1993) of atmospheric carbon in response to climate change scenarios. In northern Alaska, USA, direct evidence shows soil acting as a $\mathrm{CO}_{2}$ source over a 5 yr period (Oechel et al. 1993)

•E-mail: rouse@mcmail.cis.mcmaster.ca
On a diurnal, seasonal and annual basis, $\mathrm{CO}_{2}$ emission rates are commonly explained by 2 sets of environmental variables. Solar radiation, atmospheric temperature and humidity, and ambient $\mathrm{CO}_{2}$ concentrations affect rates of photosynthesis. The thermal and hydrologic regimes of the substrate influence microbial processes and respiration and can also have an indirect influence on photosynthesis (Burton 1994). The change from carbon accumulation to carbon loss in northern ecosystems could, for example, be influenced by increasing air temperature and as a result soil temperature, and by enhanced drainage and soil aeration due to decreased soil moisture. General Circulation Model results indicate that globally averaged surface temperatures could rise by 1.5 to $4.5^{\circ} \mathrm{C}$ when the atmospheric $\mathrm{CO}_{2}$ concentration is doubled (IPCC 1990). High latitudes are expected to undergo the greatest increases in surface temperature (Rizzo \& Wilken 1992), thus disturbing the equilibrium of the natural carbon cycle within permafrost regions. Consequently, understanding the factors that control $\mathrm{CO}_{2}$ emission and uptake is important in predicting the 


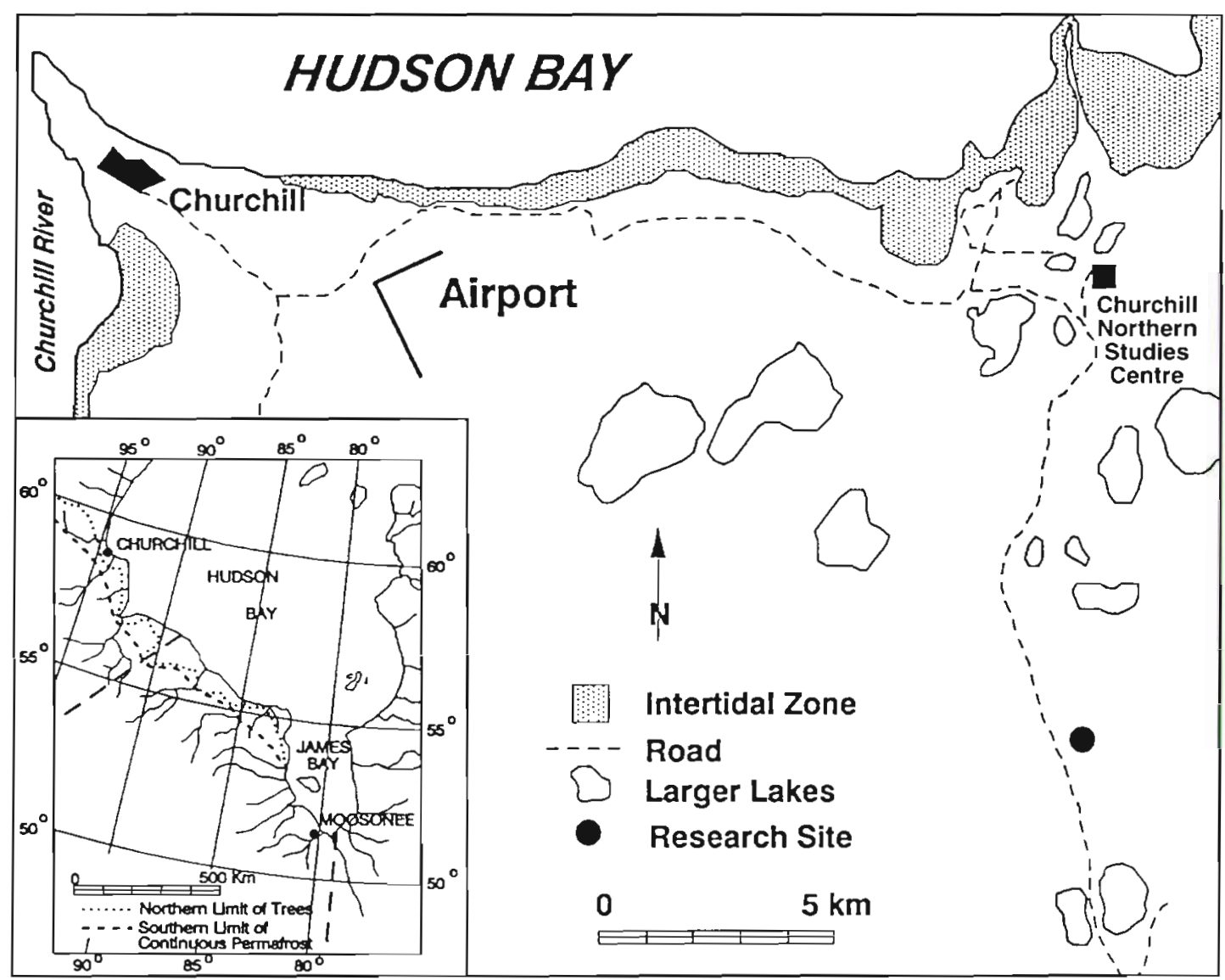

Fig. 1. Location of research area and site

uncertain effects of global climate change on the carbon balance of northern peatlands.

A general need is recognized for the use of controlled experiments to investigate relationships between the $\mathrm{CO}_{2}$ flux and its environmental controls. A number of these experiments have been pursued in the laboratory and in the field. Using recent study results of core microcosms of intact soils and vegetation from Alaska's North Slope, Billings et al. (1982, 1983) have suggested that peat soils in arctic regions may become net sources of $\mathrm{CO}_{2}$ to the atmosphere under different climate warming scenarios. In their studies, water table variations had greater effects upon $\mathrm{CO}_{2}$ flux in the microcosms than did warming the air temperature by $4^{\circ} \mathrm{C}$ or doubling the atmospheric concentration of $\mathrm{CO}_{2}$. Enhanced soil aeration due to a lowered water table increased microbial peat oxidation, leading to increased $\mathrm{CO}_{2}$ flux emissions from the microcosms (Peterson et al. 1984). Recently, laboratory incubations of peat columns have been shown to increase $\mathrm{CO}_{2}$ emissions more than 4 -fold when the water table dropped from the surface to a depth of $0.40 \mathrm{~m}$ in one experiment (Glenn et al. 1993) and 3 -fold when the water table went from the surface to a depth of $0.15 \mathrm{~m}$ in another experiment (Funk et al. 1994). These observations confirm the evidence of Moore \& Knowles (1989) who found that water table lowering substantially increased $\mathrm{CO}_{2}$ loss from peat columns. Gradient flux and eddy correlation measurements from an open bog in the southern Hudson Bay Lowland during peak growing season in July indicated a small net daily uptake of $\mathrm{CO}_{2}$ over a time-averaged diurnal period, although negative and positive flux rates in the daytime and nighttime, respectively, were nearly equal (Neumann et al. 1994).

This study uses similar methodology to that of Neumann et al. (1994) and allows some comparison of the carbon budget between the northern and southern Hudson Bay Lowland. It also can be compared to the few wetland tundra studies done elsewhere. It incorporates an analysis of the effects of soil temperature and soil moisture on $\mathrm{CO}_{2}$ flux rates and overall emission totals using field measurements. 


\section{STUDY AREA AND MEASUREMENT SITE}

The northern Hudson Bay Lowland in the vicinity of Churchill, Manitoba, Canada (Fig. 1) is a large coastal plain in which wetlands occupy 85 to $90 \%$ of the surface (Riley 1990). The coastal plain rises from sea level to about $150 \mathrm{~m}$ where it meets the Canadian Shield (Mortsch 1990). Because of isostatic uplift at the rate of about $1 \mathrm{~m}$ per $100 \mathrm{yr}$, the landscape near Hudson Bay is younger than that which lies inland. Soils are classified as gleysolic, developing under hydrophytic vegetation or tundra plant communities. In the Churchill region they are always found in combination with organic soils which are primarily formed from decayed sedges and mosses. The water table lies above the mineral substrate for most or all of the year (Mortsch 1990). Day-to-day temperature and humidity changes during the summer growing season are very large. This arises from the fact that winds blowing from Hudson Bay are colder and moister than those from the continental interior (Rouse 1991). Thus in terms of photosynthesis and respiration there is the potential to monitor substantial effects from changing air and soil temperatures.

The research site is located $18 \mathrm{~km}$ southeast of Churchill and $12.5 \mathrm{~km}$ south of the Hudson Bay coastline (Fig. 1). The site is an extensive, flat sedge wetland located in the northern part of the Hudson Bay Lowland physiographic region. The study site is classified as a fen (Zoltai \& Pollett 1983). At an elevation of $22 \mathrm{~m}$ a.s.l. the landscape is approximately 2200 yr old. The research area is underlain by continuous permafrost and is characterized by hummocky terrain. The substrate is composed of highly porous peat, averaging $0.25 \mathrm{~m}$ thick, covering a thick layer of glaciomarine silty clay. The primary vascular plant on the hummocks is Carex aquatilis which is also found on the drier margins of the hollows. Less common are Ledum decumbens, Salix arctophila and Betula glandulosa. The moss Scorpidium turgescens (Scott pers. comm. 1994) covers up to $23 \%$ of the surface of the hollows and comprises $15 \%$ of the total surface area of the site (Coxson pers. comm. 1993). In terms of flux measurements, the fen is very extensive and uniform in all directions (Fig. 2) so that boundary layer adjustment of the wind field presents no restrictions (Wessel \& Rouse 1994).

\section{INSTRUMENTATION AND METHODS}

\section{1. $\mathrm{CO}_{2}$ flux measurements}

Carbon dioxide sampling was conducted on 27 days throughout the midsummer period from July 17 to August 24, 1993. The $\mathrm{CO}_{2}$ system (Figs. 2 \& 3) em- ployed the flux-gradient methodology (den Hartog et al. 1994, Neumann et al. 1994). Six air intakes were located above a hummock and at $0.35,0.7,1.1,1.6$ and $2.3 \mathrm{~m}$, within psychrometer housings mounted on a climatological tower. Air was drawn by two $12 \mathrm{~V}$ pumps (Model TD-4N, Brailsford \& Co. Inc., Rye, NY, USA) through $6.5 \mathrm{~m}$ of non- $\mathrm{CO}_{2}$-absorbing flexible Bev-aline tubing which ran from the sensors to 11 buffer volumes. Air was continually drawn down from all levels to the buffer volumes by a circulation pump. A sampling pump provided the suction for only the particular level being sampled. The system was maintained at a constant flow rate of $1.51 \mathrm{~min}^{-1}$ using a flow meter. Carbon dioxide concentration was sampled every $10 \mathrm{~s}$ and averaged at half-hour intervals. Thus 30 measurements were averaged for each level over the half-hour period.

The $\mathrm{CO}_{2}$ system employed an amplifier panel which contained the electronics necessary to sequentially switch and monitor six $12 \mathrm{~V}$ solenoid-actuated valves. Sampling sequencing and duration were controlled by a datalogger (Model 21X, Campbell Scientific, Logan, UT,

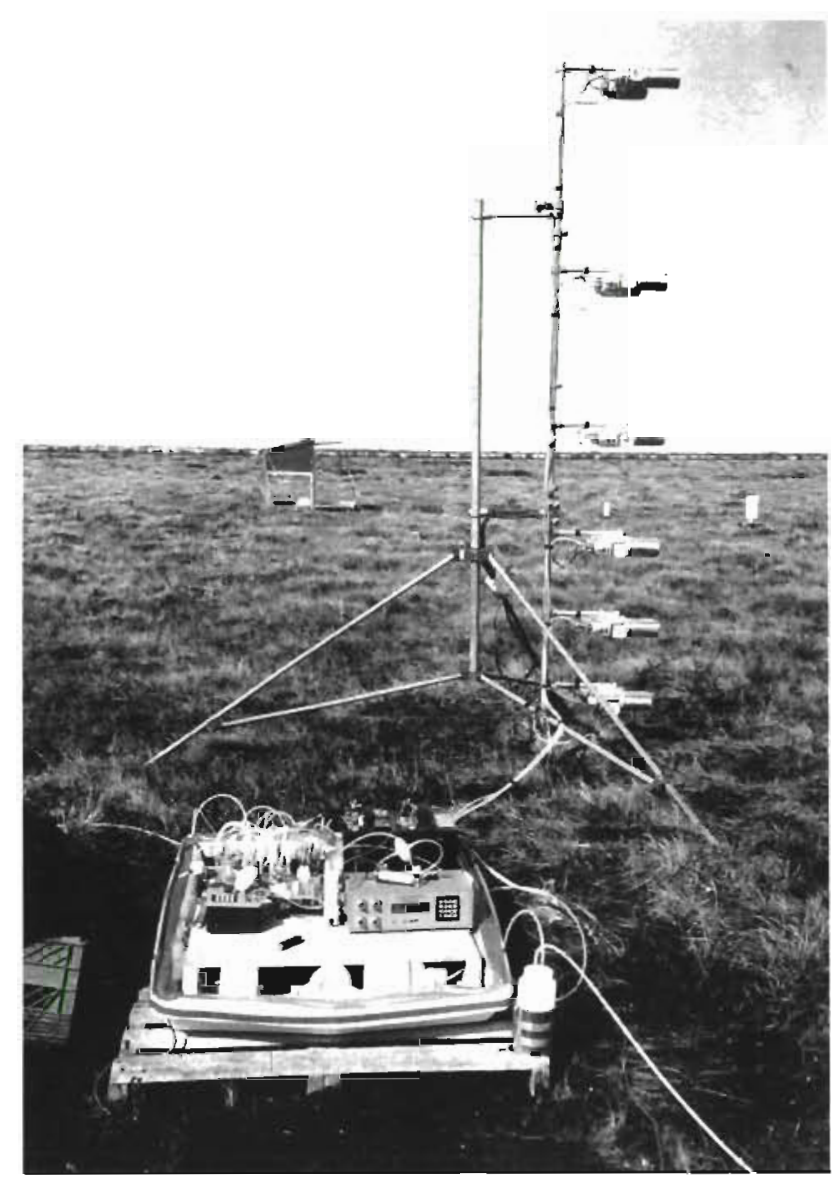

Fig. 2. The Bowen ratio energy balance (BREB) $\mathrm{CO}_{2}$ tower situated in the hummocky sedge fen 


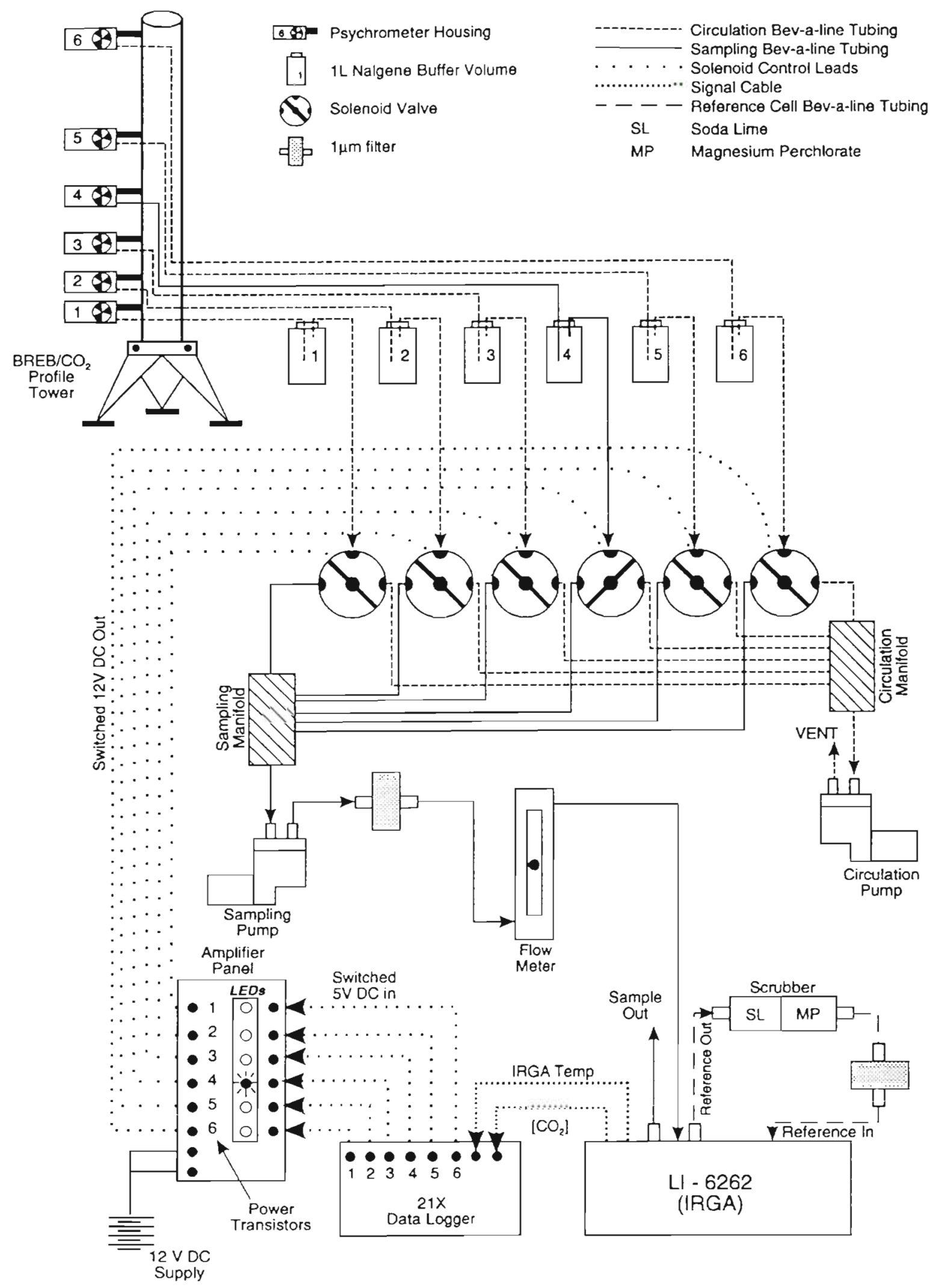

Fig. 3. Schematic diagram of $\mathrm{CO}_{2}$ flux-gradient system with level 4 being sampled 
USA). Absolute measurements of $\mathrm{CO}_{2}$ concentration at each level were obtained by a non-dispersive infrared gas analyzer (Model LI-6262, LI-COR Inc., Lincoln, NE, USA) operated at high resolution. Each of these components was housed in an insulated cartop carrier located $2 \mathrm{~m}$ from the base of the climatological tower (Fig. 2).

Calibration of the infrared gas analyzer (IRGA) was performed every other day using ultra high purity nitrogen (UHP $\mathrm{N}_{2}$ ) and an analyzed span gas of $\mathrm{CO}_{2}$ (334 ppmv) balanced in air. The use of gradient methodology in the calculation of the $\mathrm{CO}_{2}$ flux is unaffected by any offsets generated by the use of UHP $\mathrm{N}_{2}$ as a $\mathrm{CO}_{2}$-free gas. Soda lime and magnesium perchlorate in the IRGA's scrubbers were periodically changed throughout the season to absorb residual moisture and $\mathrm{CO}_{2}$ in the reference cell loop.

\subsection{Ancillary measurements}

Solar radiation $(K \downarrow)$, photosynthetically active solar radiation (PAR) and net radiation $\left(Q^{*}\right)$ were measured with an Eppley black and white pyranometer (Model 8-48), LI-COR quantum flux density sensor (Model LI190SB) and Middleton net pyrradiometer (Model $C N 1)$, respectively. The subsurface heat flux $\left(Q_{\mathrm{G}}\right)$ was measured with Middleton soil heat flux plates (Model CN3) for hummock, flat and hollow surfaces, which were corrected for the difference in thermal conductivity of the transducer and organic soil using the methodology of Rouse \& Bello (1985). Correction of the heat flux plates also involved using the calorimetric method (Halliwell \& Rouse 1987), which allows for the transfer of heat due to water movement in the soil. The latent heat flux $\left(Q_{E}\right)$ and the sensible heat flux $\left(Q_{H}\right)$ are derived from the Bowen ratio energy balance (BREB) calculations employing 6-level profiles of atmospheric temperature and vapor pressure (Fig. 2), which have proved accurate and reliable in many studies (e.g. Halliwell \& Rouse 1989, Rouse 1991, Wessel \& Rouse 1994). Rainfall was measured using both manual and tipping bucket rain gauges and depth to the water table was measured daily in a well (ABS plastic tube). Soil temperatures were measured in a profile with thermocouples at depths of $0,0.05,0.10,0.20,0.30$, $0.40,0.50,0.60,0.70,0.80$ and $0.90 \mathrm{~m}$.

\section{THEORY OF $\mathrm{CO}_{2}$ FLUX GRADIENT MEASUREMENT}

The raw $\mathrm{CO}_{2}$ flux, $F_{\mathrm{c}}$, can be calculated as

$$
F_{\mathrm{c}}=-K_{\mathrm{c}} \cdot \frac{\partial \overline{\rho_{\mathrm{c}}}}{\partial z}
$$

where $K_{\mathrm{c}}$ is the turbulent transfer coefficient for $\mathrm{CO}_{2}$, and $\partial \overline{\rho_{c}} / \partial z$ is the mean $\mathrm{CO}_{2}$ density gradient $\left(\mathrm{kg} \mathrm{m}^{-3}\right)$. From the measured sensible heat flux, $Q_{\mathrm{H}}$, and assuming similarity of transfer coefficients, $K_{\mathrm{c}}$ is equivalent to

$$
K_{\mathrm{c}}=K_{\mathrm{h}}=\frac{-Q_{\mathrm{H}}}{(\partial T / \partial z) c_{\mathrm{p}} \overline{\rho_{\mathrm{a}}}}
$$

where $K_{\mathrm{h}}$ is the turbulent transfer coefficient for sensible heat, $\partial T / \partial z$ is the temperature gradient, $c_{p}$ is the specific heat of dry air and $\overline{\rho_{a}}$ is the density of dry air. Transforming $\partial \overline{\rho_{\mathrm{c}}} / \partial z$ into a finite difference and making use of the measured $\mathrm{CO}_{2}$ concentration gradient $\Delta \bar{C} / \Delta z$ (in ppmv $\mathrm{m}^{-1}$, equivalent to $\mu \mathrm{mol} \mathrm{mol}^{-1}$ ) gives

$$
\frac{\Delta \overline{\rho_{c}}}{\Delta z}=\overline{\rho_{\mathrm{a}}} \frac{m_{\mathrm{c}}}{m_{\mathrm{a}}} \frac{\Delta \bar{C}}{\Delta z} \cdot 10^{-6} \frac{\mathrm{mol}}{\mu \mathrm{mol}}
$$

where $m_{\mathrm{c}} / m_{\mathrm{a}}$ is the ratio of the molecular weight of $\mathrm{CO}_{2}$ to the molecular weight of dry air. Upon applying this conversion

$$
F_{c}=-\frac{-Q_{\mathrm{H}}}{(\Delta T / \Delta z) C_{\mathrm{p}}} \frac{m_{\mathrm{c}}}{m_{\mathrm{a}}} \frac{\Delta \bar{C}}{\Delta z} \cdot 10^{-6} \frac{\mathrm{mol}}{\mu \mathrm{mol}}
$$

Simplifying and collecting the constants into the following term

$$
\lambda=\frac{m_{\mathrm{c}}}{m_{\mathrm{a}}} \frac{10^{-6}}{c_{\mathrm{p}}}
$$

reduces the equation for $F_{\mathrm{c}}$ to

$$
F_{c}=\lambda \frac{Q_{H}}{\Delta T / \Delta z} \frac{\Delta \bar{C}}{\Delta z}
$$

in $\mathrm{kg} \mathrm{m}^{-2} \mathrm{~s}^{-1}$. Following the convention of flux-gradient measurements, carbon loss from the biomass to the atmosphere is positive while carbon uptake by the biomass is negative (Neumann et al. 1994). The Webb correction (Webb et al. 1980) was then applied to account for density changes due to the flux of latent heat.

\section{ENVIRONMENTAL CONDITIONS}

Measurements over the 1993 field campaign represent a climatically normal season in Churchill. Average air temperature was $11.3^{\circ} \mathrm{C}$, slightly higher than the 30 yr normal of $10.5^{\circ} \mathrm{C}$ measured at the Churchill weather station. Strong temperature fluctuations are promoted by onshore and offshore winds and are apparent in Fig. 4. Precipitation over the 1993 field season totalled $106 \mathrm{~mm}$ ( $70 \mathrm{~mm}$ over the $\mathrm{CO}_{2}$ measurement period) which was almost equal to the $30 \mathrm{yr}$ normal of $113 \mathrm{~mm}$ (Phillips 1990).

The response of the water table to rain events is very rapid (Fig. 5a). The maximum draw-down of the water table to $-0.27 \mathrm{~m}$ was recorded on July 30 . The largest rain event of the season, at $21 \mathrm{~mm}$, was recorded the 


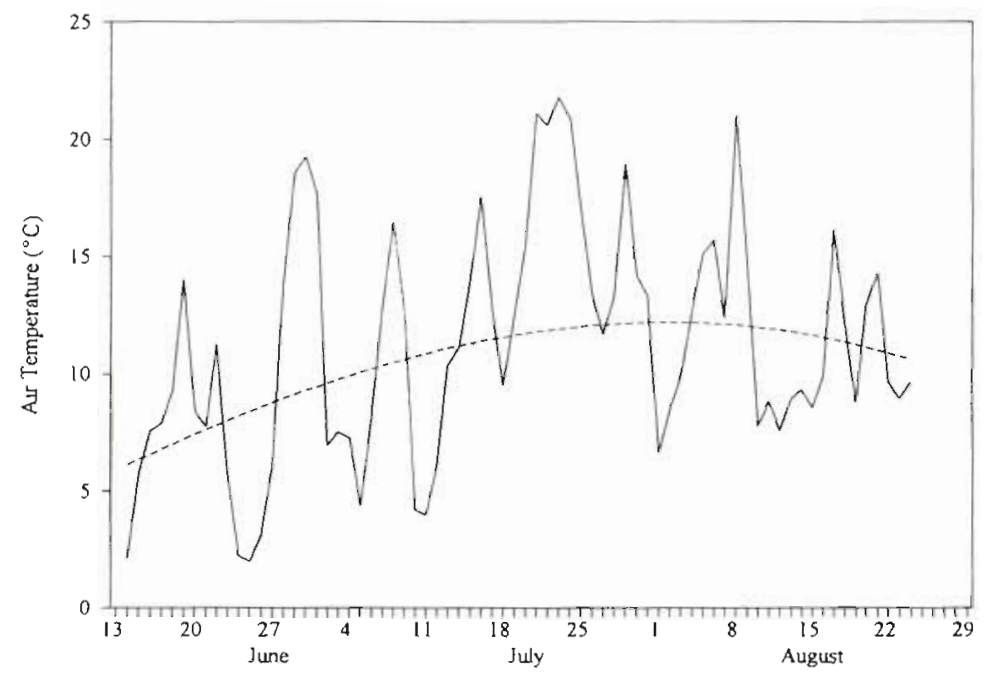

Fig. 4. Seasonal pattern of air temperature (solid line) compared to the long-term mean (dashed line)

following day (Fig. 5b). This elevated the water table $0.17 \mathrm{~m}$ over a period of $24 \mathrm{~h}$. It is evident that the depth of unsaturated soil available for aerobic microbial processes changes rapidly in this wetland. For analysis purposes, the period of $\mathrm{CO}_{2}$ flux measurements was

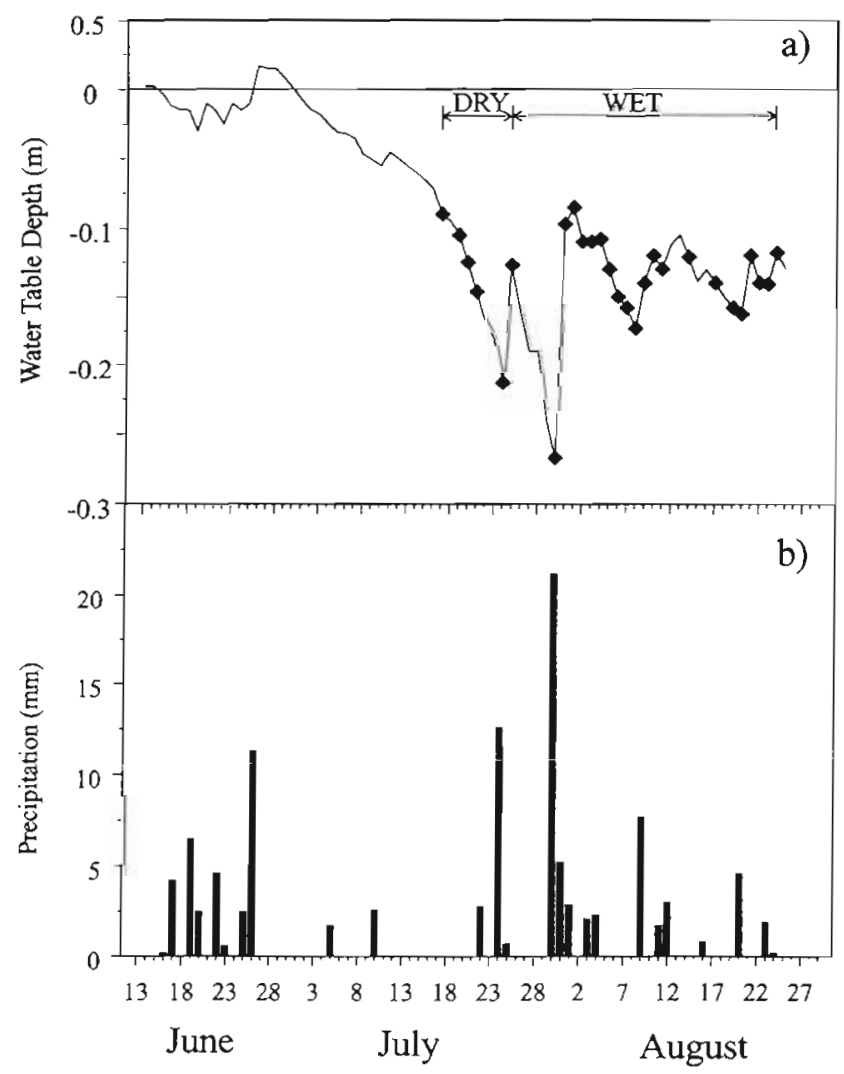

Fig. 5. (a) Depth to water table and (b) precipitation over the 1993 field season. ( $\bullet$ ) Days when $\mathrm{CO}_{2}$ flux was measured divided on the basis of depth to water table, into a dry period (July 17 to 29) and a wet period (July 30 to August 24). Dryness is only a relative term since there was normally some standing water in the hollows. The relationship of the water table to the hummocky organic terrain during the dry and the wet periods is shown in Fig. 6. The change in average water table position from dry to wet periods represents an average change in the area of the surface organic soils of about $8 \%$ from aerobic to anaerobic conditions. During the dry period, a depth of approximately $0.25 \mathrm{~m}$ of organic soil in the hummocks was aerobic. During the wet period the depth of the aerobic layer in the hummocks was approximately $0.23 \mathrm{~m}$. The bases of the hollows were entirely anaerobic during both the dry and wet periods.

Climatic characteristics of the dry compared to the wet period are outlined in Table 1. Solar radiation, photosynthetically active solar radiation and net radiation were 39 to $46 \%$ higher during the dry period, due partly to its occurrence near the summer solstice but mainly due to less cloud cover. The evaporation and ground heat flux were respectively 60 and $68 \%$ higher in the dry period, while the rainfall was $40 \%$ less. Soil temperatures in the top $0.05 \mathrm{~m}$ were $4^{\circ} \mathrm{C}$ higher in the dry period. In general, the dry period was substantially sunnier, warmer and drier than the wet period.

The ambient $\mathrm{CO}_{2}$ concentrations in the surface soils and lower atmosphere are shown in Fig. 7 for a period when coincident atmospheric and soil $\mathrm{CO}_{2}$ measurements were available. Static diffusion chambers were used to obtain the soil surface concentrations, while the subsurface concentrations were obtained by a membrane diffusion measurement system pioneered by Coxson \& Parkinson (1987) with the results reported in Whelpdale (1993). The measurements are for a nocturnal period of respiration and indicate changes in $\mathrm{CO}_{2}$ concentrations from about 600 ppm at a depth of $0.10 \mathrm{~m}$ in the soil to $400 \mathrm{ppm}$ at the soil surface to $340 \mathrm{ppm}$ in the atmosphere. It is apparent that on August 15, when the water table was at $-0.14 \mathrm{~m}$, the surface soil layers served as a major reservoir of $\mathrm{CO}_{2}$ which was potentially available throughout the midsummer measurement period.

\section{RESULTS}

\section{1. $\mathrm{CO}_{2}$ fluxes and concentrations}

The net flux, $F_{c}$, varied from strongly positive during most of the July measurement days to a mixture of 


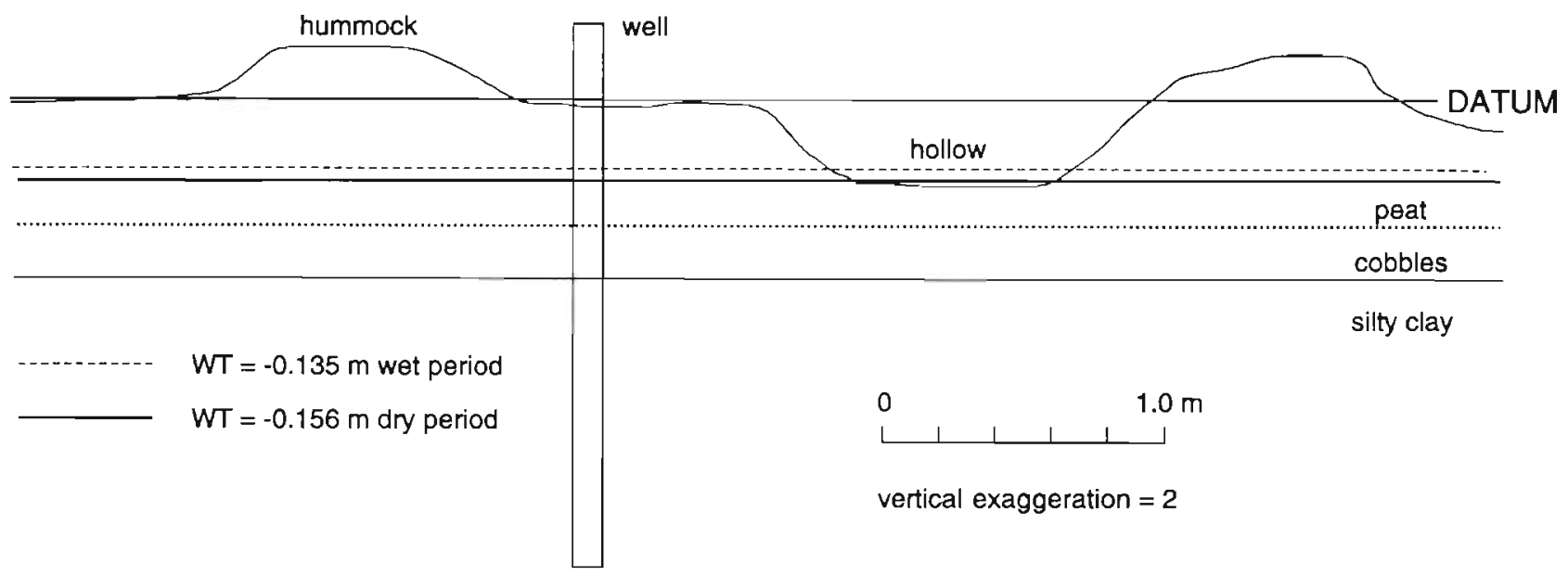

Fig. 6. Schematic diagram of the position of the water table during the dry and wet periods relative to organic soils in hummocks and hollows

Table 1. Environmental conditions during dry and wet periods, $K \downarrow$ : global solar radiation $\left(\mathrm{W} \mathrm{m}^{-2}\right)$; PAR: photosynthetically active radiation $\left(\mathrm{W} \mathrm{m}^{-2}\right) ; Q^{\cdot}$ : net radiation $\left(\mathrm{W} \mathrm{m}^{-2}\right) ; Q_{\mathrm{E}}$ : latent heat flux $\left(\mathrm{W} \mathrm{m}^{-2}\right) ; Q_{\mathrm{H}}$ : sensible heat flux $\left(\mathrm{W} \mathrm{m}^{-2}\right)$; $Q_{\mathrm{G}}$ : ground heat flux $\left(\mathrm{W} \mathrm{m}^{-2}\right) ; \beta=Q_{\mathrm{H}} / Q_{\mathrm{E}}$ P: precipitation ( $\left.\mathrm{mm} \mathrm{d}^{-1}\right)$; $E$; evaporation $\left(\mathrm{mm} \mathrm{d}^{-1}\right) ; W T$ : depth to water table $(\mathrm{m}) ; W T_{\max }$ : maximum depth to water table $(\mathrm{m}) ; T_{0}$; soil temperature at surface $\left({ }^{\circ} \mathrm{C}\right) ; T_{05}$ : soil temperature at $0.05 \mathrm{~m}$ $\left({ }^{\circ} \mathrm{C}\right) ; T_{10}$ : soil temperature at $0.10 \mathrm{~m}\left({ }^{\circ} \mathrm{C}\right) ; T_{20}$ : soil temperature at $0.20 \mathrm{~m}\left({ }^{\circ} \mathrm{C}\right)$

\begin{tabular}{|c|c|c|c|c|c|}
\hline & Dry period & Wet period & & Dry period & Wet period \\
\hline$K \downarrow$ & 232 & 167 & $P$ & 1.24 & 1.73 \\
\hline PAR & 125 & 86 & $E$ & 2.79 & 1.73 \\
\hline$Q^{\bullet}$ & 135 & 91 & $W T$ & -0.156 & -0.135 \\
\hline$Q_{E}$ & 79 & 49 & $W T_{\max }$ & -0.273 & -0.172 \\
\hline$Q_{H}$ & 36 & 31 & $T_{0}$ & 16.1 & 11.5 \\
\hline$Q_{G}$ & 19 & 11 & $T_{05}$ & 15.1 & 11.7 \\
\hline \multirow[t]{2}{*}{$\beta$} & 0.46 & 0.63 & $T_{10}$ & 12.7 & 10.2 \\
\hline & & & $T_{20}$ & 8.6 & 7.7 \\
\hline
\end{tabular}

negative and positive $F_{\mathrm{c}}$ during August (Fig. 8). On average for all days of measurement, $F_{c}$ showed a net efflux of $0.013 \mathrm{mg} \mathrm{m}^{-2} \mathrm{~s}^{-1}$. However, there was an order of magnitude difference from 0.042 during the dry period to $0.004 \mathrm{mg} \mathrm{m}^{-2} \mathrm{~s}^{-1}$ during the wet period. Thus the impact of soil condition is evident and is explored further below.

The diurnal pattern of atmospheric $\mathrm{CO}_{2}$ concentrations (Fig. 9) is characteristic of vegetated surfaces in summer (Oke 1987). $\mathrm{CO}_{2}$ concentrations increase following sunset through the night and reach a peak in the early morning. Concentrations decrease rapidly following sunrise and remain relatively small throughout the daytime. There is much larger diurnal range in July than in August because nocturnal respiration rates are higher in July. This is due to 2 factors. The July data correspond to the dry period and also the period of most vigorous sedge growth. The respiration from the warm, dry soils and the plants was additive. The August data represent the wet period when colder, moister soils favoured lower respiration fluxes.

The average diurnal pattern of $F_{\mathrm{c}}$ (Fig. 10) indicates the following. The net efflux starts at $18: 00 \mathrm{~h}, 2 \mathrm{~h}$ prior to sunset, and reaches a maximum about 01:00 $\mathrm{h}$ the following morning. This is the period when soils are warm and photosynthesis is minimal or absent. The net efflux decreases from 01:00 h and becomes nil at 06:00 h, 1.5 h after sunrise. Daytime net photosynthesis increases rapidly after 06:00 h, reaching a peak at 08:00 $\mathrm{h}$, and shows strong $\mathrm{CO}_{2}$ uptake until solar noon. In the afternoon it plateaus at moderate values before returning to a net efflux state at 18:00 h.

\subsection{Environmental controls}

Daytime photosynthesis occurred in response to the plants' regulation of $\mathrm{CO}_{2}$ and $\mathrm{H}_{2} \mathrm{O}$. The $\mathrm{CO}_{2}$ uptake pattern (Fig. 10) tracks the stomatal conductance of the vegetation as described by Blanken \& Rouse (1996). This is characterized in Carex aquatilis by high conductance in the early morning, followed by a smaller midday and early afternoon conductance. A second smaller peak conductance follows in late afternoon. Such a pattern is promoted by changing air temperatures and changing leaf-to-air vapor pressure deficits. In terms of Fig. 10, the photosynthesis peak in the morning corresponds to maximum stomatal conduc- 


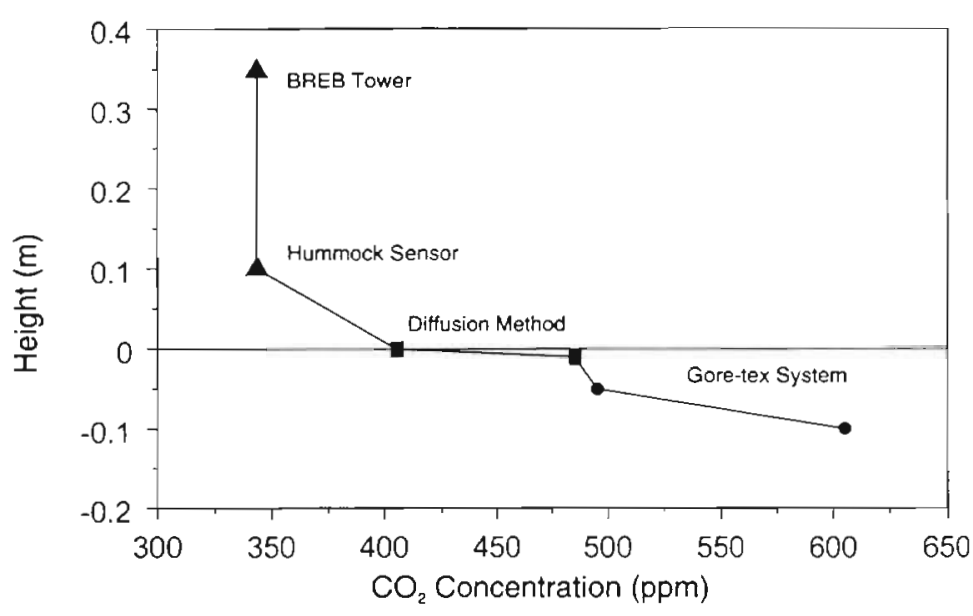

Fig. 7. Profile of $\mathrm{CO}_{2}$ concentrations using a combination of flux gradient measurements ( $₫)$, static chamber diffusion measurements ( $\bullet$ ) and membrane diffusion measurements ( $\bullet$ ) for the period 02:00 to 06:00 $\mathrm{h}$, August 15

indicate that on a seasonal basis, as both WT and $T_{\mathrm{s}}$ increase, $\mathrm{CO}_{2}$ efflux (respiration) increases.

\subsection{Respiration and photosynthesis}

$F_{\mathrm{c}}$ was divided into a respiration and photosynthesis flux in the following approximation. For each day, the nighttime $\mathrm{CO}_{2}$ flux was assumed to represent the minimum daytime respiration flux, $F_{\mathrm{R}(\mathrm{mm})}$. This assumes that daytime respiration rates are probably somewhat higher than the nighttime ones given the substantially higher soil temperatures. During the daytime the minimum photosynthesis flux, $F_{P(\min )}$, becomes the difference between the net daytime flux, $F_{\mathrm{c}}$ and $F_{\mathrm{R}(\min )}$ where

$$
F_{\mathrm{P}(\min )}=F_{\mathrm{c}}-F_{\mathrm{R}(\operatorname{men})}
$$

Table 2. Spearman rank correlation coefficients $\left(\mathrm{r}_{\mathrm{s}}\right)$ for mean daily regressions of the net $\mathrm{CO}_{2}$ efflux $\left(F_{\mathrm{c}}\right.$-pos) and net $\mathrm{CO}_{2}$ uptake $\left(F_{\mathrm{c}}\right.$-neg) on soil temperature, $T_{\mathrm{s}}$ and depth to water table, $W T$. Correlations apply to the 0.05 confidence level

\begin{tabular}{|cccc|}
\hline & $T_{\mathrm{s}}$ & $W T$ & Significant \\
\hline$F_{\mathrm{c} \text {-neg }}$ & 0.67 & 0.52 & No/Yes \\
$F_{\mathrm{c} \text {-pos }}$ & 0.24 & 0.21 & Yes/Yes \\
\hline
\end{tabular}

tance. However, by late afternoon, net photosynthesis does not correspond to the second stomatal conductance peak, presumably because increased photosynthesis is offset by increased respiration.

The mean daily $F_{c}$ over the midsummer season was not distributed normally and the nonparametric Spearman rank test was used to investigate its associations with specific environmental variables. The analysis was performed using a 1 -tailed test at the 0.05 confidence level. In Table 2 , $F_{c}$-neg refers to those days when there was a net photosynthetic uptake of $\mathrm{CO}_{2}$ and $F_{c}$ pos refers to those days when there was a net respiration loss. The Spearman rank correlation coefficient indicated that the relationship between $F_{c}$-neg and $F_{c}$-pos and depth to water table, WT, was significant on a daily basis. This indicates that as the water table depth increases the magnitude of both $F_{c}$-neg and $F_{c}$-pos also increases. Also significant is the direct relationship between $F_{\mathrm{c}}$-pos and the mean daily soil temperature, $T_{s}$. Both results
The results calculated for each $24 \mathrm{~h}$ period and averaged over the full measurement season are shown in Table 3. $F_{\mathrm{R}(\operatorname{mun})}$ is more than twice as high during the dry period compared to the wet period.

Table 3 indicates that this procedure gives an average $F_{\mathrm{P}(\min )}$ which is $80 \%$ higher and an average $F_{\mathrm{R}(\min )}$ which is $140 \%$ higher in the dry period than in the wet period. One would assume that $F_{\mathrm{P}(\min )}$ during the dry period, which was drier, sunnier and warmer with greater transpiration (Table 1) and stomatal conductance, would be higher than during the wet period. These results are conjectural and it is clear that $F_{\mathrm{R}(\min )}$ is substantially higher under warmer and drier soil conditions than with a cooler and wetter soil environment.

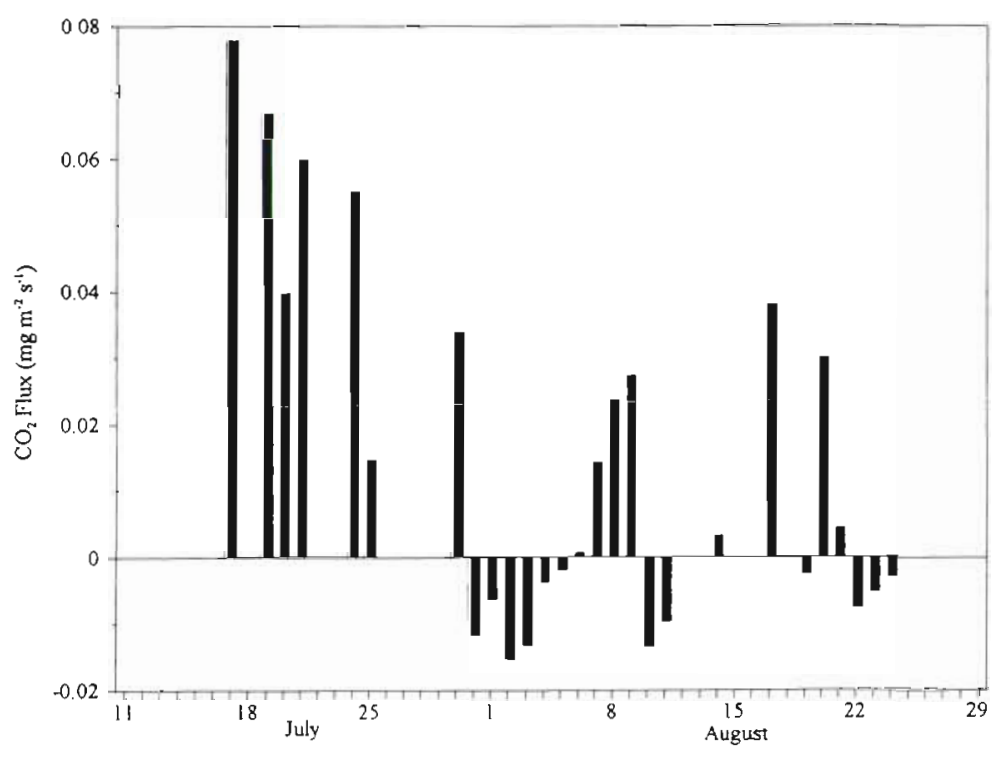

Fig. 8. Daily averages of the net $\mathrm{CO}_{2}$ flux over the measurement period 


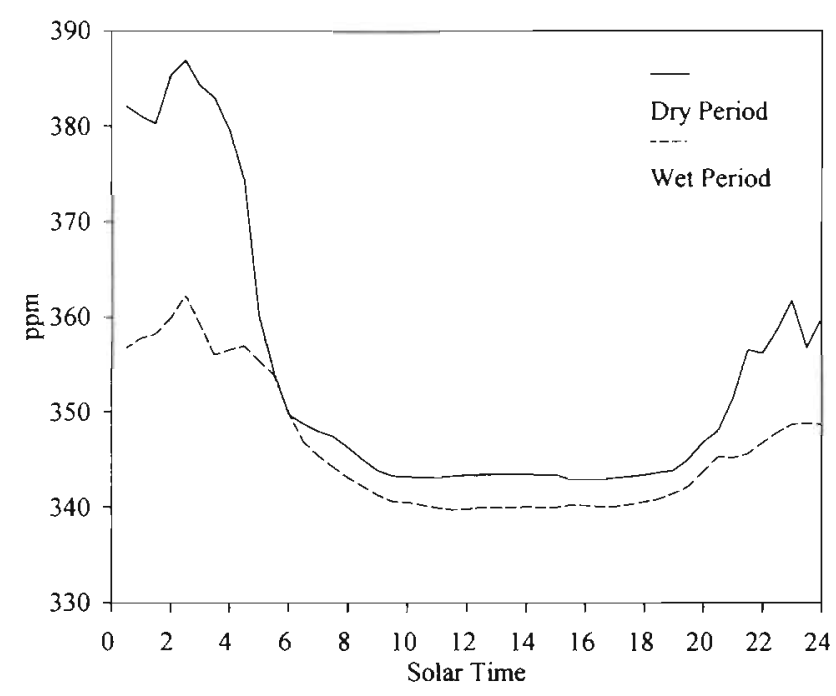

Fig. 9. Diurnal patterns of $\mathrm{CO}_{2}$ concentrations for dry (solid line) and wet (dashed line) periods

\section{DISCUSSION}

The 2 most important results of this study are that there is net $\mathrm{CO}_{2}$ loss during the midsummer period when photosynthesis is most active, and the striking difference in the $\mathrm{CO}_{2}$ budget between dry and wet periods.

Table 3. Net $\mathrm{CO}_{2}$ flux, $F_{\mathrm{c}}$ (measured), minimum respiration flux, $F_{\mathrm{R}(\min )}$, and photosynthesis flux, $F_{\mathrm{P}(\min ) \cdot}$ averaged for dry and wet periods $\left(\mathrm{mg} \mathrm{m}^{-2} \mathrm{~s}^{-1}\right)$

\begin{tabular}{|lccc|}
\hline & $F_{\mathrm{C}}$ & $F_{\mathrm{R}(\mathrm{mun})}$ & $F_{\mathrm{P}(\text { min })}$ \\
\hline Dry period & 0.042 & 0.134 & -0.092 \\
Wet period & 0.004 & 0.055 & -0.051 \\
\hline
\end{tabular}

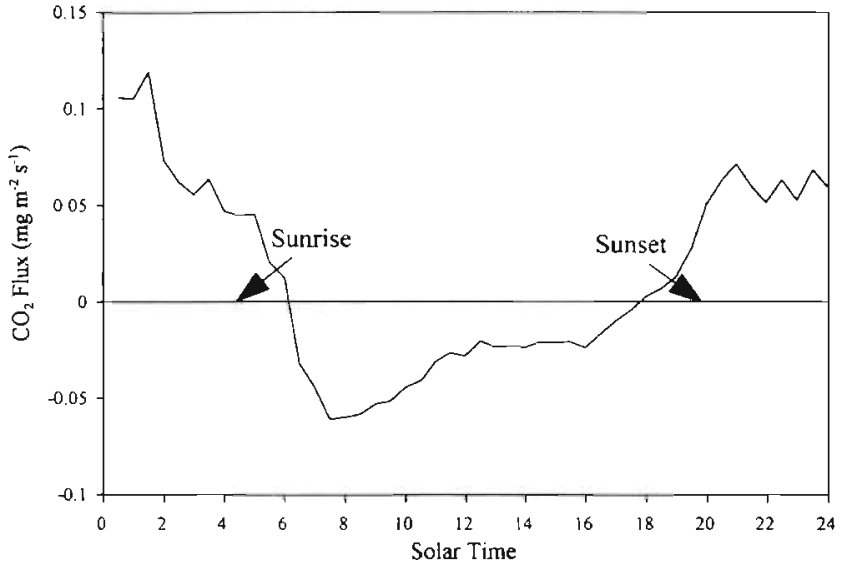

Fig. 10. Diurnal pattern of the seasonally averaged net $\mathrm{CO}_{2}$ flux. Note that sunrise occurs at 04:30 h and sunset occurs at 20:00 h

The first observation is in agreement with several other high latitude studies (Table 4). Recent Alaskan studies indicate a net loss of $\mathrm{CO}_{2}$ during the growing season. In contrast, however, a study in the southern Hudson Bay Lowland (HBL) (Neumann et al. 1994) found a net $\mathrm{CO}_{2}$ uptake. In Table 4 , the net $\mathrm{CO}_{2}$ flux difference between the Neumann et al. (1994) study and the others is possibly a result of the vegetation that characterizes the southern HBL site. In addition to mosses and lichens, the southern HBL site supported shrub and tree species, while the sites in Alaska and Churchill were dominated by sedges and grasses.

Over the approximately 2200 yr since marine emergence of the study site, there has been an accretion of about $0.40 \mathrm{~m}$ of organic soils on the hummocks and about $0.10 \mathrm{~m}$ in the hollows. If one assumes a continuous steady rate of peat accumulation, this site would be

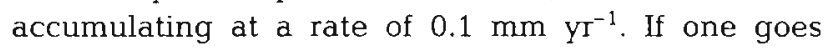

Table 4. Current estimates of mean $\mathrm{CO}_{2}$ flux $\left(\mathrm{g} \mathrm{m}^{-2} \mathrm{~d}^{-1}\right)$ in arctic and subarctic ecosystems. Negative sign indicates net uptake

\begin{tabular}{|c|c|c|c|c|c|}
\hline Study & Ecosystem & Location & Duration & Method & $\mathrm{CO}_{2}$ flux \\
\hline $\begin{array}{l}\text { Oberbauer et al. } \\
(1992)\end{array}$ & $\begin{array}{l}\text { Sedge riparian } \\
\text { tundra }\end{array}$ & $\begin{array}{l}\text { Imnavait Creek, Alaska } \\
\left(68^{\circ} 38^{\prime} \mathrm{N}, 149^{\circ} 25^{\prime} \mathrm{W}\right)\end{array}$ & $\begin{array}{l}\text { June } 18-J u l y \\
24,1990\end{array}$ & Dynamic chamber & 1.60 \\
\hline This study & Subarctic sedge fen & $\begin{array}{l}\text { Churchill, Manitoba } \\
\left(58^{\circ} 45^{\prime} \mathrm{N}, 94^{\circ} 04^{\prime} \mathrm{W}\right)\end{array}$ & $\begin{array}{l}\text { July-August } \\
1993(27 \mathrm{~d})\end{array}$ & $\begin{array}{l}\text { Bowen ratio } \\
\text { energy balance }\end{array}$ & 1.12 \\
\hline $\begin{array}{l}\text { Oechel et al. } \\
\text { (1993) }\end{array}$ & Wet coastal tundra & $\begin{array}{l}\text { Prudhoe Bay, Alaska } \\
\left(70^{\circ} 22^{\prime} \mathrm{N}, 148^{\circ} 45^{\prime} \mathrm{W}\right)\end{array}$ & Summer 1990 & $\begin{array}{l}\text { Ecosystem cuvette and } \\
\text { gas exchange system }\end{array}$ & 0.35 \\
\hline $\begin{array}{l}\text { Fan et al. } \\
(1992)\end{array}$ & $\begin{array}{l}\text { Wet meadow tundra } \\
\text { and upland tundra }\end{array}$ & $\begin{array}{l}\text { Bethel, Alaska } \\
\left(61^{\circ} 5.4^{\prime} \mathrm{N}, 162^{\circ} 0.9^{\prime} \mathrm{W}\right)\end{array}$ & $\begin{array}{l}\text { July-August } \\
1988 \text { (30 d) }\end{array}$ & Eddy correlation & 0.30 \\
\hline $\begin{array}{l}\text { Neumann et al. } \\
\text { (1994) }\end{array}$ & Peat bog & $\begin{array}{l}\text { Lake Kinosheo, Ontario } \\
\left(51^{\circ} 33^{\prime} \mathrm{N}, 81^{\circ} 49.5^{\prime} \mathrm{W}\right)\end{array}$ & $\begin{array}{l}\text { June } 25-\text { July } \\
28,1990\end{array}$ & $\begin{array}{l}\text { Bowen ratio energy balance } \\
\text { and eddy correlation }\end{array}$ & -1.70 \\
\hline
\end{tabular}


inland $60 \mathrm{~km}$ the landscape is about $5000 \mathrm{yr}$ old and organic soils on the order of $1.0 \mathrm{~m}$ deep are observed (Dredge 1979). Using the same assumptions as above, the older landscape has been accumulating peat at a rate of $0.2 \mathrm{~mm} \mathrm{yr}^{-1}$. If our evidence is indicative of the contemporary average condition, the processes that might be causing a net loss rather than a net accumulation of carbon in the organic soils in the present day need to be discovered. Causes might be related to a decrease in rates of photosynthesis or to an increase in the rates of respiration or both. A decrease in photosynthetic rates might be due to less sunlight, fewer nutrients, drier and cooler conditions or a combination of 2 or more of these factors. An increase in respiration would most likely be related to warmer and/or drier conditions. The long-term climatic evidence indicates a general warming in this area of $0.5^{\circ} \mathrm{C}$ during the last century (Skinner \& Gullett 1993). There has been no statistically significant change in precipitation during the historical record which dates back to 1943 . Thus a somewhat warmer and drier scenario appears to represent the contemporary scene.

The second important observation in this study indicates that a relatively small change in soil moisture content and temperature can promote a substantial change in $\mathrm{CO}_{2}$ loss. Thus for the dry period, in which the surface soils were $4^{\circ} \mathrm{C}$ warmer and the water table $0.02 \mathrm{~m}$ lower, the net carbon loss was an order of magnitude greater than in the wet period. Since the dry period was sunnier and underwent more evapotranspiration, one can assume a greater photosynthesis, which is supported by the results in Table 3 . However, the greater respiration more than compensated for enhanced photosynthesis. Our tentative hypothesis is that warmer and drier summer conditions can promote substantially increased net $\mathrm{CO}_{2}$ losses and that general 20th century warming may, at least temporarily, be reversing the more general situation of net carbon fixation in these peatlands.

\section{CONCLUSIONS}

Under normal midsummer climatic conditions there is a consistent net daily $\mathrm{CO}_{2}$ loss from wet-sedge tundra to the atmosphere. The magnitude of the $\mathrm{CO}_{2}$ loss is comparable to, but near the high end of, other recent studies. The $\mathrm{CO}_{2}$ loss increases with warmer and drier soil conditions which strongly increase respiration rates from the organic soils. Further study of the relationship between the thermal and hydrologic regime of the peat substrate and $\mathrm{CO}_{2}$ flux may indicate that carbon accumulation in peat soils has been temporarily reversed in response to warmer temperatures and resulting higher and drier soil conditions.
Acknowledgements. The authors thank Darwyn Coxson for providing membrane diffusion $\mathrm{CO}_{2}$ measurements for this study and Cheryl Schreader for her assistance in the field. Financial assistance for this research was provided by the National Science and Engineering Research Council of Canada (W.R.R.) and a northern student training grant from the Department of Indian and Northern Affairs (K.L.B.). Logistical support was provided by the Churchill Northern Studies Centre.

\section{LITERATURE CITED}

Billings WD, Luken JO, Mortensen DA, Peterson KM (1982) Arctic tundra: a source or sink for atmospheric carbon dioxide in a changing environment? Oecologia 53:7-11

Billings WD, Luken JO, Mortensen DA, Peterson KM (1983) Increasing atmospheric carbon dioxide: possible effects tundra. Oecologia 58:286-289

Blanken PD, Rouse WR (1996) Evidence of water conservation mechanisms in several subarctic wetland species. J Appl Ecol (in press)

Burton KL (1994) The midsummer carbon dioxide budget of a subarctic sedge wetland. MSc thesis, McMaster University, Hamilton, Ontario

Coxson DS, Parkinson D (1987) Winter respiratory activity in aspen woodland forest floor litter and soils. Soil Bio Biochem 19:49-59

den Hartog G, Neumann HH, King KM, Chipanshi AC (1994) Energy budget measurements using eddy correlation and Bowen ratio techniques at the Kinosheo Lake tower site during the Northern Wetlands Study. J Geophys Res 99: 1539-1549

Dredge LA (1979) Thaw depth and permafrost in polygonal peat terrain, Hudson Bay Lowland, Manitoba. In: Current Research, Part C. Geol Surv Can Pap 79-1C:27-30

Fan SM, Wofsy SC, Bakwin PS, Jacob DJ, Anderson SM, Kebabian PL, McManus JB, Kolb CE (1992) Micrometeorological measurements of $\mathrm{CH}_{4}$ and $\mathrm{CO}_{2}$ exchange between the atmosphere and subarctic tundra. J Geophys Res 97:16627-16643

Funk DW, Pullman ER, Peterson KM, Crill PM, Billings WD (1994) Influence of water table on carbon dioxide, carbon monoxide, and methane fluxes from taiga bog microcosms. Global Biogeochem Cycles 8:271-278

Glenn MS, Heyes A, Moore TR (1993) Carbon dioxide and methane fluxes from drained peat soils, southern Quebec. Global Biogeochem Cycles 7:247-257

Gorham E (1991) Northern peatlands: role in the carbon cycle and probable responses to climatic warming. Ecol Appl 1: $182-195$

Halliwell DH, Rouse WR (1987) Soil heat flux in permafrost: characteristics and accuracy of measurement. J Climatol $7: 571-584$

Halliwell DH, Rouse WR (1989) A comparison of sensible and latent heat flux calculations using the Bowen ratio and aerodynamic methods. J Atmos Ocean Technol 6:563-574

Harrison K, Broecker W, Bonani G (1993) A strategy for estimating the impact of $\mathrm{CO}_{2}$ fertilization on soil carbon storage. Global Biogeochem Cycles 7:69-80

Houghton RA (1991) Tropical deforestation and atmospheric carbon dioxide. Clim Change 19:99-118

IPCC (1990) Climate Change: the IPCC Scientific Assessment. Carnbridge University Press, Cambridge, p 138

Moore TR, Knowles R (1989) The influence of water table levels on methane and carbon dioxide emissions from peatland soils. Can J Soil Sci 69:33-38 
Mortsch L (1990) Eastern Canadian boreal and subarctic wetlands: a resource document. Climatological Studies No. 42, Atmospheric Environment Service, Environment Canada, Downsview, Ontario, p 168

Neumann HH, den Hartog G, King KM, Chipanshi AC (1994) Carbon dioxide fluxes over a raised open bog at Kinosheo Lake tower site during the Northern Wetlands Study (NOWES). J Geophys Res 99:1529-1538

NWWG (1988) Wetlands of Canada: Ecological Land Classification Series, No. 24. Sustainable Development Branch, Environment Canada, Ottawa, and Polyscience Publications Inc., Montreal, Quebec, p 452

Oberbauer SF, Gillespie CT, Cheng W, Gebauer R, Sala Serra A, Tenhunen JD (1992) Environmental effects on $\mathrm{CO}_{2}$ efflux from riparian tundra in the northern foothills of the Brooks Range, Alaska, USA. Oecologia 92:568-577

Oechel WC, Hastings SJ, Vourlitis G, Jenkins M, Riechers G, Grulke N (1993) Recent change of Arctic tundra ecosystems from a net carbon dioxide sink to a source. Nature 361:520-523

Oke TR (1987) Boundary layer climates, 2nd edn. Methuen, New York, p 112, 128

Peterson KM, Billings WD, Reynolds DN (1984) Influence of water table and atmospheric $\mathrm{CO}_{2}$ concentration on the carbon balance of arctic tundra. Arct Alp Res 16: 331-335

Phillips D (1990) The climates of Canada. Ministry of Supply and Services Canada, Ottawa

Riley JL (1990) The vascular plants of the Hudson Bay Lowland and their postglacial origins. Ontario Ministry of Natural Resources Parks and Recreational Areas Section, Central Region, Richmond Hill, p 222

Editor: V. Meentemeyer, Athens, Georgia, USA
Rizzo B, Wilken E (1992) Assessing the sensitivity of Canada's ecosystems to climatic change. Clim Change 21:37-55

Rouse WR (1991) Impacts of Hudson Bay on the terrestrial climate of the Hudson Bay Lowlands. Arct Alp Res 23:24-30

Rouse WR, Bello RL (1985) Impact of Hudson Bay on the energy balance in the Hudson Bay lowlands and the potential for climatic modification. Atmos-Ocean 23:375-392

Skinner WR, Gullett DW (1993) Trends of daily maximum and minimum temperature in Canada during the past century. Clim Bull 27:63-77

Tans PP, Fung IY, Takahashi T (1990) Observational constraints on the global atmospheric $\mathrm{CO}_{2}$ budget. Science 247:1431-1438

Townsend AR, Vitousek PM, Holland EA (1992) Tropical soils could dominate the short-term carbon cycle feedbacks to increased global temperatures. Clim Change 22:293-303

Webb EK, Pearman GI, Leuning R (1980) Correction of flux measurements for density effects due to heat and water vapour transfer. Q J R Meteorol Soc 106:85-100

Wessel DA, Rouse WR (1994) Modelling evaporation from wetland tundra. Boundary-Layer Meteorol 68:109-130

Whelpdale E (1993) Soil respiration in a subarctic peatland. BSc thesis, McMaster University, Hamilton, Ontario

Woodwell GM (1983) Biotic influences on the concentration of atmospheric carbon dioxide: a review and projection. In: Changing climate, Carbon Dioxide Assessment Committee. National Academy Press, Oxford, p 216-241

Zoltai SC, Pollett FC (1983) Wetlands in Canada: Their classification, distribution and use. In: Gore AJP (ed) Ecosystems of the world, Vol 4B. Mires: swamp, bog, fen and moor-regional studies. Elsevier Scientific Publishing Company, New York, p 249

Manuscript first received: July 14, 1995

Revised version accepted: November 28, 1995 